\title{
Hubungan ASI Eksklusif dengan Kejadian Underweight di Jawa Timur Tahun 2016
}

\section{The Relationship of Exclusive Breastfeeding and Underweight in East Java in 2016}

\author{
Mahmudah Wati Sugito*1, Agus Sri Wardoyo ${ }^{2}$, Trias Mahmudiono ${ }^{1}$
}

\begin{abstract}
ABSTRAK
Latar Belakang: Masalah gizi kurang merupakan masalah kesehatan masyarakat yang disebabkan oleh banyak faktor. Prevalensi underweight di Jawa Timur tahun 2016 sebesar 17,3\%, lebih tinggi dari target program Dinas Kesehatan Provinsi Jawa Timur sebesar 12,9\%. ASI merupakan makanan terbaik untuk mendukung pertumbuhan dan perkembangan bayi. Cakupan ASI Eksklusif di Jawa Timur tahun 2015 menurun (68,8\%), dibandingkan tahun 2014 (72,89\%). Pemberian makanan pendamping ASI dini pada bayi di bawah 6 bulan dapat mempengaruhi status gizi.

Tajuan: Tujuan penelitian untuk menganalisis hubungan ASI Ekslusif dengan kejadian underweight pada bayi usia 0-23 bulan di Provinsi Jawa Timur tahun 2016.

Metode: Penelitian ini merupakan analisis data sekunder survei Pemantauan Status Gizi Provinsi Jawa Timur. Populasi penelitian adalah semua bayi berusia 0-59 bulan yang ada di Jawa Timur. Total sampel sebanyak 4738 bayi. Analisis data dilakukan dengan menggunakan uji Chi-square dan Regresi Logistik.

Hasil: Hasil penelitian menunjukkan ada hubungan antara pemberian ASI saja sejak lahir sampai sebelum 24 jam terakhir pada bayi usia 0-23 bulan dengan kejadian underweight $(\mathrm{p}=0,000010 ; \mathrm{OR}=1,654 ; 95 \% \mathrm{Cl}=1,319-2,052)$, ada hubungan pertama kali memberikan makanan selain ASI pada bayi usia 0-23 bulan dengan kejadian underweight, $(p=0,000 ; 0 R=0,272$; $95 \% \mathrm{Cl}=0,217-0,341)$.

Kesimpulan: Simpulan yaitu pemberian ASI saja pada bayi sejak lahir sampai sebelum 24 jam terakhir dan pertama kali memberikan makanan selain ASI pada bayi usia 0-23 bulan berhubungan dengan kejadian underweight. Pemberian ASI saja sudah mencukupi kebutuhan nutrisi bayi usia 0-6 bulan.
\end{abstract}

Kata Kunci: ASI Ekslusif, status gizi, underweight 


\begin{abstract}
Background: Underweight is a public health problem caused by many factors. The prevalence of underweight in East Java in 2016 was 17.3\%, wich was higher than the program's targetted (12.9\%). Breast milk is the best food to support the growth and development of the baby. Coverage of Exclusive Breast Milk in East Java in 2015 decreased (68.8\%), compared to 2014 (72.89\%). Early supplementary feeding in infants under 6 months may affect nutritional status.

Objectives: The purpose of this study was to analyze the relationship of Exclusive Breast milk with the incidence of underweight in infants aged 0-23 months in East Java Province in 2016.

Method: This study is a secondary data analysis of Nutrition Status Monitoring in East Java Province. The study population was all babies in East Java. Total sample is 4738. The data were analyzed using Chi-square test and Logistic Regression, with 95\% Cl ( $\alpha=0.05)$.

Results: The results showed there was a significant relationship between exclusive breastfeeding only from birth until before the last 24 hours in infants aged 0-23 months with the incidence of underweight, with $(\mathrm{p}=0.000010 ; \mathrm{OR}=1.654 ; 95 \% \mathrm{Cl}=1.319-2.052)$, there was a significant relationship of first to provide a food other than breast milk in infants aged 0-23 months with the occurrence of underweight, $(p=0.000 ; O R=0.272 ; 95 \% \mathrm{Cl}=0.217-0.341)$.

Conclusion: In conclusion, breastfeeding only in infants from birth until before the last 24 hours and first provide food other than breast milk in infants aged 0-23 months associated with underweight. Because breast milk is sufficient nutritional needs of infants aged 0-6 months.
\end{abstract}

Keywords: Exclusive Breastfeeding, nutrition status, underweight

\footnotetext{
*Koresponden:

mahmudahwati@gmail.com

${ }^{1}$ Departemen Gizi Kesehatan, Fakultas

Kesehatan Masyarakat-Universitas Airlangga

${ }^{2}$ Seksi Kesehatan Keluarga dan Gizi

Masyarakat- Dinas Kesehatan Provinsi Jawa

Timur
} 


\section{PENDAHULUAN}

Masalah gizi kurang merupakan
masalah kesehatan masyarakat yang disebabkan oleh berbagai faktor, sehingga upaya penanggulangannya tidak cukup dengan pendekatan medis maupun pelayanan kesehatan saja ${ }^{1}$. Asupan makanan dan penyakit infeksi merupakan penyebab langsung, sedangkan penyebab tidak langsung yaitu perilaku, ketersediaan pangan rumah tangga, dan pelayanan kesehatan. Faktorfaktor lain penyebab gizi buruk adalah kemiskinan, rendahnya pendidikan, dan kesempatan kerja ${ }^{2}$. Prevalensi kasus gizi buruk di Provinsi Jawa Timur tahun 2016 sebesar 3,4\%, sedangkan target Rencana Strategis Provinsi Jawa Timur Tahun 2016 sebesar $2 \%^{3}$. Prevalensi kasus underweight sebesar $17,3 \%$, sedangkan target program Dinas Kesehatan Provinsi Jawa Timur sebesar $12,9 \%{ }^{4}$.

ASI mengandung zat gizi yang cukup untuk mengoptimalkan pertumbuhan dan perkembangan bayi. Menurut Keputusan Menteri Kesehatan No. 450 Tahun 2004 tentang pemberian ASI secara eksklusif pada bayi Indonesia yaitu "Pemberian ASI eksklusif, diwajibkan bagi bayi baru lahir sampai bayi berumur 6 bulan dan dianjurkan dilanjutkan sampai anak berusia 2 tahun dengan pemberian makanan tambahan yang sesuai" ${ }^{5}$. ASI tidak memberatkan kerja organ pencernaan dan ginjal. Kandungan gizi ASI diantaranya adalah karbohidrat berupa laktosa, asam lemak tak jenuh ganda, protein laktalbumin, vitamin, mineral, kalsium, serta zat-zat untuk pencegahan infeksi dan alergi ${ }^{6}$.

Menurut data Riset Kesehatan Dasar (Riskesdas) tahun 2013, pemberian ASI eksklusif pada bayi sampai berusia 6 bulan hanya $38 \%$. Bayi yang mendapat ASI Eksklusif di Jawa Timur tahun 2015 sebesar 68,8\%", mengalami penurunan dibandingkan dengan tahun 2014 (72,89\%), tetapi kembali meningkat pada tahun 2016 sebesar $75 \%^{8}$. Bayi yang tidak diberi ASI eksklusif selama 6 bulan dapat mempengaruhi status gizi. Pemberian ASI eksklusif dapat membantu mencegah penyakit infeksi pada bayi ${ }^{9}$. Penyakit infeksi akan menurunkan nafsu makan pada bayi dan berakibat penurunan status gizi. Berdasarkan penelitian Susanti, dari 50 bayi yang tidak diberi ASI Eksklusif, $76,7 \%$ diantaranya menderita gizi buruk ${ }^{10}$. Status gizi kurang energi, vitamin $A, Z n, F e$ menyebabkan bayi sering mengalami infeksi yang berlangsung lama ${ }^{11}$.

Penelitian Puput di Rumah Sakit Kediri bahwa bayi yang semakin lama diberi ASI, dapat menurunkan kejadian diare ${ }^{12}$. Penyakit infeksi akan menurunkan nafsu makan bayi dan status gizi. Penelitian Nur dan Marissa tentang riwayat pemberian ASI dengan penyakit infeksi pada balita dari data Susenas Provinsi Aceh 2012, bahwa ada hubungan signifikan pemberian ASI eksklusif dengan kejadian infeksi. Balita yang tidak diberikan ASI eksklusif selama enam bulan berisiko 1,4 kali lebih tinggi mengalami penyakit infeksi ${ }^{13}$. Penelitian Istyaningrum pada bayi usia 6-24 bulan di Kelurahan Bendungan Kecamatan Cilegon tahun 2010, menunjukkan bahwa bayi yang tidak diberi ASI eksklusif lebih banyak yang menderita diare sebesar $66 \%$, daripada yang diberi ASI eskklusif 12,5\%. Bayi yang tidak diberi ASI eksklusif berpeluang sebesar 13 kali terkena diare dibandingkan bayi yang diberi ASI eksklusif ${ }^{14}$.

Sedangkan penelitian Putra di Puskesmas Kenali Besar, pemberian susu formula pada bayi usia 0-6 bulan memiliki risiko 6,250 kali terkena diare dibandingkan bayi yang diberikan ASI eksklusif ${ }^{14}$. ASI mengandung antibodi IgA sekretori (SigA). Pada saat menyusui, slgA berpengaruh terhadap paparan mikroorganisme pada saluran cerna bayi. SIgA membatasi bakteri yang masuk ke dalam aliran melalui mukosa saluran cerna. Menyusui dapat melindungi bayi baru lahir dari infeksi ${ }^{15}$.

Rumusan masalah penelitian ini adalah "Apakah terdapat hubungan pemberian ASI eksklusif dengan kejadian underweight pada bayi usia 0-23 bulan di Provinsi Jawa Timur tahun 2016 ? Tujuan dari penelitian ini adalah menganalisis hubungan pemberian ASI eksklusif dengan kejadian underweight pada bayi usia 0-23 bulan di Provinsi Jawa Timur tahun 2016. Manfaat dari penelitian ini adalah memperoleh gambaran dan analisis hubungan pemberian ASI eksklusif dengan kejadian 
underweight pada bayi usia 0-23 bulan di Provinsi Jawa Timur tahun 2016, serta mengetahui pentingnya pemberian ASI Eksklusif agar status gizi nya baik.

\section{METODE}

Penelitian ini merupakan analisis data sekunder survei Pemantauan Status Gizi di Provinsi Jawa Timur tahun 2016. Survei Pemantauan Status Gizi merupakan survei rutin tahunan yang dilakukan Dinas Kesehatan Provinsi Jawa Timur dengan responden sejumlah 12098 balita. Data sekunder diperoleh dari seksi kesehatan keluarga dan gizi masyarakat Dinas Kesehatan Provinsi Jawa Timur. Populasi penelitian adalah semua bayi yang ada di Provinsi Jawa Timur.

Pemantauan status gizi terkait ASI Eksklusif ada 2 cara, yaitu dengan variabel pemberian ASI saja sejak lahir sampai sebelum 24 jam terakhir pada bayi usia 0-23 bulan dan kapan pertama kali memberikan makanan selain ASI. Sampel adalah bayi yang berusia 023 bulan. Besar sampel untuk variabel pemberian ASI saja sejak lahir sampai sebelum 24 jam terakhir pada bayi usia 0-23 bulan dan pertama kali memberikan makanan selain ASI adalah 4749 sampel. Setelah dilakukan cleaning data dengan menghilangkan data missing, besar sampel adalah 4738 sampel. Variabel dependen adalah kejadian underweight dan variabel independen adalah pemberian ASI saja sejak lahir sampai sebelum 24 jam terakhir dan pertama kali pemberian makanan selain ASI.

Pengolahan dan analisis data menggunakan uji Chi Square dan Regresi Logistik. Uji regresi logistik dilaksanakan karena pada variabel dependen berskala dikotomi (nominal dengan 2 kategori). Tujuan penggunaan regresi logistik adalah untuk memperkirakan besarnya probabilitas kejadian tertentu di dalam suatu populasi dan faktor apa saja yang berpengaruh signifikan terhadap suatu kejadian.

\section{HASIL DAN PEMBAHASAN}

Berdasarkan tabel 1, bayi usia 0-23 bulan yang diberi ASI saja sejak lahir sampai sebelum 24 jam terakhir sebesar $77 \%$, sedangkan yang tidak diberi ASI saja sejak lahir sampai sebelum 24 jam terakhir sebesar $23 \%$. Berdasarkan tabel 2, bayi usia 0-23 bulan yang pertama kali diberi ASI $<30$ hari sebesar $46,2 \%$, sedangkan yang diberi ASI $\geq 30$ hari sebesar 53,8\%. Dengan demikian, lebih banyak bayi yang diberi ASI $\geq 30$ hari.

Tabel 1. Distribusi frekuensi pemberian ASI saja sejak lahir sampai sebelum 24 jam terakhir

\begin{tabular}{lcc}
\hline $\begin{array}{c}\text { Pemberian ASI saja } \\
\text { sejak lahir sampai } \\
\text { sebelum 24 jam } \\
\text { terakhir }\end{array}$ & \multicolumn{2}{c}{ Jumlah } \\
\cline { 2 - 3 } & $\mathbf{n}$ & $\%$ \\
\hline Ya & 3646 & 77,0 \\
Tidak & 1092 & 23,0 \\
\hline Total & 4738 & 100,0 \\
\hline
\end{tabular}

Tabel 2. Distribusi frekuensi pertama kali pemberian makanan selain ASI

\begin{tabular}{lcc}
\hline \multirow{2}{*}{$\begin{array}{c}\text { Pertama kali } \\
\text { pemberian makanan } \\
\text { selain ASI }\end{array}$} & $\mathbf{n}$ & Jumlah \\
\cline { 2 - 3 } & 2188 & 46,2 \\
\hline 30 hari & 2550 & 53,8 \\
\hline 30 hari & 4738 & 100,0 \\
\hline Total & & \\
\hline
\end{tabular}

Tabel 3. Hasil Uji Chi Square Variabel Independen dengan Kejadian Underweight

\begin{tabular}{|c|c|c|c|c|}
\hline \multirow[b]{2}{*}{ Variabel } & & \multicolumn{2}{|c|}{ Status Gizi } & \multirow[b]{2}{*}{$p$ value } \\
\hline & & $\begin{array}{l}\text { Tidak } \\
\text { Underweight }\end{array}$ & Underweight & \\
\hline $\begin{array}{l}\text { Pemberian ASI saja sejak lahir } \\
\text { sampai sebelum } 24 \text { jam terakhir } \\
\text { Pertama kali pemberian makanan } \\
\text { selain ASI }\end{array}$ & $\begin{array}{l}\text { Ya } \\
\text { Tidak } \\
<30 \text { hari } \\
\geq 30 \text { hari }\end{array}$ & $4090(86,3 \%)$ & $648(13,7 \%)$ & 0,000003 \\
\hline
\end{tabular}


Tabel 4. Hasil Uji Regresi Logistik Variabel Independen dengan Kejadian Underweight

\begin{tabular}{|c|c|c|c|c|c|c|}
\hline \multirow[b]{2}{*}{ Variabel } & & \multicolumn{2}{|c|}{ Status Gizi } & \multirow[b]{2}{*}{ OR } & \multirow[b]{2}{*}{$95 \% \mathrm{Cl}$} & \multirow[b]{2}{*}{ p-value } \\
\hline & & $\begin{array}{l}\text { Tidak } \\
\text { Underweight }\end{array}$ & Underweight & & & \\
\hline 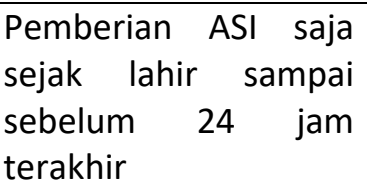 & $\begin{array}{l}\text { Ya } \\
\text { Tidak }\end{array}$ & $4090(86,3 \%)$ & $648(13,7 \%)$ & 1.645 & $\begin{array}{l}1,319 \\
- \\
2,052\end{array}$ & 0,000010 \\
\hline $\begin{array}{lr}\text { Pertama } & \text { kali } \\
\text { pemberian } & \text { makanan } \\
\text { selain ASI } & \end{array}$ & $\begin{array}{l}<30 \text { hari } \\
\geq 30 \text { hari }\end{array}$ & $4317(91,1 \%)$ & $421(8,9 \%)$ & 0,272 & $\begin{array}{l}0,217- \\
0,341\end{array}$ & 0,000 \\
\hline
\end{tabular}

Berdasarkan tabel 3, diperoleh hasil bahwa nilai pearson Chi-Square, $p=0,000003$, yang berarti ada perbedaan pemberian ASI saja sejak lahir sampai sebelum 24 jam terakhir dengan kejadian underweight. Nilai pearson Chi-Square $\mathrm{p}<\alpha=0,05, \mathrm{p}=0,000$, yang berarti bahwa ada perbedaan kapan pertama kali memberikan cairan/makanan selain ASI dengan kejadian underweight.

Berdasarkan tabel 4, Hasil uji regresi logistik, nilai $p=0,000010$. Pemberian ASI saja sejak lahir sampai 24 jam terakhir berpengaruh secara signifikan terhadap kejadian underweight. Nilai OR sebesar 1,654 yang berarti balita yang tidak diberi asi saja sejak lahir sampai 24 jam terakhir memiliki risiko 1,654 kali menderita underweight dengan nilai $\mathrm{Cl}(1,319-2,052)$ dibandingkan dengan bayi yang diberi ASI esksklusif. Bayi yang diberi ASI saja sejak lahir sampai sebelum 24 jam terakhir lebih banyak yang tidak underweight $(85,1 \%)$ daripada yang underweight $(9,6 \%)$.

Hasil penelitian Andriani, dkk, nilai $p=$ 0,000 , terdapat hubungan antara pemberian ASI eksklusif dengan kejadian status gizi kurang pada balita usia 1-5 tahun. Bayi yang diberikan ASI eksklusif selama 6 bulan dapat mencegah gizi kurang ${ }^{16}$. Penelitian Widyastuti, pada bayi 6-12 bulan di Provinsi NTB , pemberian ASI eksklusif pada bayi usia 6-12 bulan dapat mencegah gizi kurang $(p=0,003$, OR $=0,441, \quad$ Cl 95\%: 0,256-0,760) $)^{17}$. Penelitian Putri, ada perbedaan status gizi bayi usia 0-6 bulan yang tidak diberi ASI eksklusif dan diberi ASI eksklusif di BPS Suratmi Bantul Yogyakarta. Semakin sering bayi usia 0-6 bulan diberikan ASI maka status gizinya semakin baik.
Penelitian Aziezah pada bayi usia 6-12 bulan di Puskesmas Ngagelrejo menunjukkan bahwa distribusi status gizi bayi yang diberi ASI eksklusif mengalami status gizi kurang sebesar $0 \%$ dibandingkan dengan yang status gizi normal $100 \%$,sedangkan yang tidak ASI Eksklusif, mengalami status gizi kurang sebesar $41,20 \%$ dibandingkan dengan yang status gizi normal $58,80 \%{ }^{19}$.

Berdasarkan tabel 5, Hasil uji regresi logistik, nilai $p=0,000$, yang berarti ada pengaruh signifikan pertama kali pemberian makanan selain ASI terhadap kejadian underweight. Bayi yang diberikan makanan selain ASI $\geq 30$ hari berisiko underweight sebesar 0,272 kali lipat, dibandingkan bayi yang diberi makanan selain ASI < 30 hari. Semakin lama bayi yang tidak PMT maka semakin rendah risikonya untuk gizi buruk. Penelitian Wargiana, Risa, dkk , di wilayah kerja Puskesmas Rowotengah Kabupaten Jember, hasil uji Chi Square yaitu nilai $\mathrm{p}=$ 0,008, ada hubungan antara pemberian makanan pendamping ASI dini dengan status gizi bayi 0-6 bulan ${ }^{20}$.

Tabel 5. Hasil crosstab pemberian ASI saja sejak lahir sampai sebelum 24 jam terakhir dengan kelompok umur dan kejadian underweight

\begin{tabular}{ccc}
\hline Usia & Underweight & $\begin{array}{c}\text { Tidak } \\
\text { underweight }\end{array}$ \\
\hline 0-5 bulan & 70 & 719 \\
& $(8,9 \%)$ & $(91,1 \%)$ \\
6-11 bulan & 98 & 1352 \\
& $(6,8 \%)$ & $(93,2 \%)$ \\
12-23 bulan & 253 & 2246 \\
& $(10,1 \%)$ & $(89,9 \%)$ \\
\hline
\end{tabular}


Berdasarkan tabel 5 , bayi usia $0-5$ bulan yang menderita underweight sebesar 70 bayi $(8,9 \%)$, sedangkan yang tidak underweight sebesar $716(91,1 \%)$. Zat gizi bagi bayi kurang dari 6 bulan sudah tercukupi hanya dengan ASI saja ${ }^{21}$. Bayi yang tidak diberi ASI saja sejak lahir sampai 24 jam terakhir yang tidak mengalami underweight salah satu faktor penyebabnya adalah kondisi imunitas bayi dan pemberian MP ASI dini belum berdampak secara langsung pada bayi usia 0-6 bulan. Bayi yang tidak diberi ASI eksklusif rentan mengalami penyakit, seperti infeksi saluran pencernaan, gizi buruk, serta gangguan tumbuh kembang, dan meningkatkan risiko kematian. Bayi dapat mengalami penurunan berat badan sebesar $7 \%$ pada 72 jam pertama kehidupan, apabila terjadi masalah dalam pemberian $\mathrm{ASI}^{22}$. Hasil studi penelitian kohort Boyd-Orr yang mempelajari dampak jangka panjang dari pemberian ASI pada masa bayi terhadap panjang badan pada masa anak-anak dan setelah dewasa, menunjukkan bahwa anak yang mendapat ASI, bermakna lebih tinggi daripada yang mendapat susu formula ${ }^{23}$.

Berdasarkan tabel 5, bayi usia 6-11 bulan yang mengalami underweight sebesar $98(6,8 \%)$ daripada yang tidak underweight sebesar 1352 (93,2\%). Bayi usia 12-23 bulan yang mengalami underweight sebesar 253 $(10,1 \%)$ daripada yang tidak underweight saja 2246 (89,9\%). Bayi usia lebih dari 6 bulan sudah membutuhkan makanan pendamping ASI untuk mencukupi kebutuhan nutrisi selain ASI. Komposisi ASI akan berubah sejalan dengan kebutuhan bayi. Pemenuhan kalori melalui ASI pada bayi usia enam bulan sudah tidak mencukupi. Semakin bertambah tumbuh kembang bayi akan bertambah pula kebutuhan nutrisi seimbang. Bayi usia lebih dari 6 bulan sudah membutuhkan makanan pendamping ASI agar kebutuhan gizi nya tercukupi dan bayi memiliki status gizi baik ${ }^{24}$. Variabel terkait ASI Eksklusif yang lebih berpengaruh terhadap kejadian underweight di Provinsi Jawa Timur adalah variabel pemberian ASI saja sejak lahir sampai sebelum 24 jam terakhir pada usia 0-23 bulan . Tetapi, pada variabel tersebut dapat terjadi bias karena adanya kesalahan persepsi terutama pemberian ASI saja pada usia lebih dari 6 bulan tanpa makanan pendamping ASI.

Salah satu kandungan ASI adalah kolostrum. Kolostrum adalah cairan yang disekresi oleh kelenjar payudara dari hari ke-1 sampai ke-4. Kolostrum berwarna kuning keemasan karena kandungan komposisi lemak yang tinggi dan sel-sel hidup. Kolostrum membersihkan mukoneum dari usus bayi baru lahir dan mempersiapkan saluran pencernaan makanan bayi. Antibodi merupakan kandungan tertinggi pada kolostrum yang bersifat protektif terhadap bayi ${ }^{25}$. Pemberian kolostrum selama satu jam pertama kelahiran bayi menjalin ikatan kasih sayang antara ibu dan bayi ${ }^{26}$.

Periode emas dua tahun pertama kehidupan anak dapat tercapai secara optimal apabila ditunjang dengan asupan nutrisi yang tepat sejak lahir. Rekomendasi World Health Organization (WHO) yaitu agar memberikan ASI eksklusif untuk bayi sampai berumur 6 bulan dan dilanjutkan makanan pendamping ASI sampai bayi berumur 2 tahun atau lebih ${ }^{27}$. Pertambahan umur bayi yang disertai kenaikan berat badan maupun tinggi badan, akan meningkatkan kebutuhan energi maupun zat gizi. Hal itu dapat dipengaruhi oleh umur, kecepatan pertumbuhan, banyaknya aktivitas fisik, penyerapan dan utilisasi makanannya6.

ASI mengandung nutrisi yang cukup dan zat kekebalan untuk melindungi balita dari infeksi ${ }^{6}$. ASI mengandung protein, lemak, vitamin, mineral, air, dan enzim yang dibutuhkan oleh bayi. Manfaat ASI yaitu, mengurangi risiko kekurangan nutrisi karena zat besi yang yang terkandung dalam ASI diserap lebih baik, pertumbuhan bakteri Lactobacillus bifidus dalam usus oleh ASI dapat mencegah bakteri penyebab penyakit lainnya dalam saluran pencernaan serta untuk mencegah terjadinya diare. ASI mengandung zat laktoferin, kolostrum ASI kaya antibodi dan zat antiinfeksi ${ }^{28}$.

Bayi yang diberi ASI, tidak mudah terpapar penyakit dan dapat berperan langsung terhadap status gizi ${ }^{29}$. Pemberian ASI yang kurang dari 6 bulan dapat disebabkan karena kurangnya pengetahuan ibu tentang pola asuh yang tepat, penggunaan susu formula, serta adanya budaya pada daerah 
tertentu seperti pemberian makanan tambahan yang terlalu dini pada bayi akibat adanya budaya turun-temurun, ataupun karena kondisi kesehatan ibu ${ }^{30}$.

Kurangnya pengetahuan ibu tentang pola asuh akan berdampak pada status gizi bayi. Pencernaan bayi pada usia kurang dari 6 bulan masih belum sempurna dan hanya dapat menerima makanan berupa ASI. Pemberian makanan pendamping ASI terlalu dini akan menyebabkan terjadinya gangguan/infeksi sehingga bayi dapat mengalami gizi buruk ${ }^{31}$. MP-ASI diberikan pada bayi umur 6-23 bulan. Bayi baru lahir memiliki kemampuan yang terbatas pada beberapa fungsi untuk mencerna, mengabsorpsi, dan memetabolisme bahan makanan. Bayi 6-9 bulan sudah siap untuk menerima makanan padat secara pertumbuhan maupun secara psikologis ${ }^{32}$.

Masa pertumbuhan dan perkembangan yang pesat adalah pada usia 0-24 bulan, usia tersebut adalah periode emas sekaligus periode kritis. Bayi dan anak yang memperoleh asupan gizi sesuai dengan tumbuh kembang optimal dapat mencapai periode emas. Sedangkan bayi dan anak yang tidak memperoleh makanan sesuai dengan kebutuhan gizi mengalami periode kritis yang akan mengganggu tumbuh kembang bayi dan anak $^{33}$.

\section{KESIMPULAN}

Pemberian ASI saja pada bayi sejak lahir sampai sebelum 24 jam terakhir dan pertama kali memberikan makanan selain ASI pada bayi usia 0-23 bulan berhubungan dengan kejadian underweight. Pemberian ASI saja sudah mencukupi kebutuhan nutrisi bayi usia 0-6 bulan.

Saran agar promosi ASI lebih ditekankan pada bayi usia 0-6 bulan, sedangkan bayi usia lebih dari 6 bulan sudah membutuhkan makananpendamping ASI. Program terkait ASI Eksklusif dipertahankan dan ditingkatkan melalui upaya promosi kesehatan dengan media audio, visual, dan audio visual, yaitu : 1) Audio, seperti talkshow promosi kesehatan dan iklan melalui radio; 2) Visual seperti poster yang bisa ditempel di tempat-tempat umum, instansi, dan sosial media, serta booklet pentingnya ASI eksklusif; 3) Audio visual melalui televisi, seperti iklan layanan masyarakat dan video melalui sosial media. Pihak pelayanan kesehatan terus memberikan edukasi dan soasialisai tentang pentingnya ASI Eksklusif kepada bayi hingga usia 6 bulan dan dilanjutkan sampai usia 2 tahun dengan makanan pendamping ASI agar kebutuhan nutrisinya terpenuhi. Bayi yang diberi ASI Eksklusif dapat mencegah terjadinya underweight.

\section{ACKNOWLEDGEMENT}

Penulis mengucapkan terima kasih kepada pihak instansi Dinas Kesehatan Provinsi Jawa Timur dan Kepala seksi beserta seluruh staff di seksi kesehatan keluarga dan gizi masyarakat yang telah membantu dalam proses pengambilan data. Penulis juga mengucapkan terimakasih kepada pembimbing magang instansi yang telah membimbing selama pelaksanaan magang.

\section{REFERENSI}

1. Supariasa, I.D.N, Bakri, B dan Fajar, I. Penilaian Status Gizi. Jakarta : EGC;2012.

2. Rencana Strategis Dinas Kesehatan Provinsi Jawa Timur Tahun 2016-2019.

3. Novitasari, Dewi. Faktor-Faktor Risiko Kejadian Gizi Buruk pada Balita yang Dirawat di RSUP Dr. Kariadi Semarang. Skripsi. Fakultas Kedokteran Universitas Diponegoro. 2012. Available from http://eprints.undip.ac.id/37466/. Diakses pada 30 Maret 2017.

4. Laporan Rutin Bulanan Gizi Tahun 2016. Dinas Kesehatan Provinsi Jawa Timur. 2016

5. Keputusan Menteri Kesehatan No. 450 Tahun 2004 tentang pemberian ASI secara eksklusif pada bayi Indonesia. Available from http://perpustakaan.depkes.go.id:8180/b itstream/123456789/1149/1/KMK45004. pdf. Diakses pada 30 April 2017.

6. Adriani, M. \& Wirjatmadi, B. Peranan Gizi Dalam Siklus Kehidupan. Jakarta: Kencana Prenadamedia Group.;2012 
7. Riset Kesehatan Dasar Provinsi Jawa Timur Tahun 2013. Dinas Kesehatan Provinsi Jawa Timur. 2013. Available from http://www.depkes.go.id/resources/dow nload/general/Hasil\%20Riskesdas\%20201 3.pdf. Diakses pada 28 April 2017.

8. Profil Kesehatan Provinsi Jawa Timur Tahun 2015. Dinas Kesehatan Provinsi Jawa Timur. 2015

9. Departemen Kesehatan RI.Pemantauan Pertumbuhan Balita. Jakarta: Direktorat Gizi Departemen Kesehatan RI;2002.

10. Susanty M, Kartika M, Hadju V, Alharini S. Hubungan pola pemberian ASI dan MPASI dengan gizi buruk pada anak 6-24 bulan di Kelurahan Panmampu Makassar. Jurnal Media Gizi Masyarakat Indonesia. 2012; 1 (2) : 97-103. Available from http://download.portalgaruda.org/article .php?article $=29763 \&$ val $=2168 \&$ title $=H U B$ UNGAN\%20POLA\%2OPEMBERIAN\%20ASI \%20DAN\%20MP\%20ASI\%20DENGAN\%20 GIZI\%20BURUK\%20PADA\%20ANAK\%20624\%20BULAN\%20DI\%20KELURAHAN\%20 PANNAMPU\%20MAKASSAR. Diakses pada 28 April 2017.

11. Almatsier, S. Prinsip Dasar Ilmu Gizi. PT. Gramedia Pustaka Umum. Jakarta;2004

12. Puput S, Victoria FS. Perilaku Pemberian ASI Terhadap Frekuensi Diare pada Anak Usia 6-24 Bulan di Ruang Anak Rumah Sakit Baptis Kediri. J Stikes RS.Baptis Kediri. 2011;4(2) 89-93

13. Nur, Abidah., Marissa, Nelly. Riwayat pemberian Air Susu Ibu dengan Penyakit Infeksi pada Balita. 2012. Jurnal Kesehatan Masyarakat Nasional. 2014; $9(2)$.

14. Istyaningrum, Yurilla. Hubungan Antara Pemberian ASI Eksklusif dengan Kejadian Diare dan Faktor-faktor Risiko pada Bayi Berusia 6-12 Bulan di Kelurahan Bendungan Kecamatan Cilegon Tahun 2010. 2010. Fakultas Kedokteran dan IImu Kesehatan Universitas Islam Negeri Syarif Hidayatullah Jakarta.

15. Roesli U dan Yohmi E. Manajemen Laktasi dalam Bedah ASI. Jakarta : FKUI; 2008, hal 45-53, 69-79

16. Andriani Rully, Wismaningsih Endah Retnani, dan Indrasari Oktovina Rizky.
Hubungan Pemberian ASI Eksklusif dengan Kejadian Status Gizi Kurang pada Balita Umur 1-5 Tahun. Jurnal Wiyata. Kesehatan Masyarakat IIK Bhakti Wiyata Kediri. 2015. Available from http://www.smkkbw.sch.id/v3/home/im ages/journal/Ippm_jurnal_83_44-

47_Rully.pdf. Diakses pada 27 April 2017.

17. Widyastuti, Endang. Hubungan Riwayat Pemberian ASI. Eksklusif Dengan Status Gizi Bayi 6-12 Bulan di Provinsi Nusa Tenggara Barat. Tesis. Program Studi Epidemiologi. Fakultas Kesehatan Masyarakat. Universitas Indonesia. 2009

18. Putri. Hubungan Frekuensi Pemberian ASI dengan Status Gizi Bayi Umur 0-6 bulan di Puskesmas Ngampilan Yogyakarta. 2008. Karya Tulis Ilmiah, Tidak dipublikasikan.

19. Aziezah, Nur dan Aadriani, Merryana. Perbedaan Tingkat Konsumsi dan Status Gizi Antara Bayi dengan Pemberian Asi Eksklusif dan Non Asi Eksklusif. Jurnal Media Gizi Indonesia. 2013; 9(1): 78-83

20. Wargiana, Risa, Susumaningrum, dan Rahmawati. Hubungan Pemberian MPASI Dini dengan Status Gizi Bayi Umur 0-6 Bulan Di Wilayah Kerja Puskesmas Rowotengah Kabupaten Jember. Jurnal Pustaka Kesehatan. 2013;1(1) : 47-53. Available from http://repository.unej.ac.id/bitstream/ha ndle/123456789/10138/Risa\%20Wargian a\%20-

$\% 20062310101005$ 1.pdf?sequence=1. Diakses pada 23 Maret 2017.

21. WHO. Global Strategy for Infant and Young Child Feeding: The Optimal Duration of Exlusive Breastfeeding, 54 ${ }^{\text {th }}$ WHA. 2005.

22. Eisenberg, E. Murkoff, HE Hathway, SE. Bayi pada tahun Pertama yang Anda Hadapi Bulan per Bulan. Jakarta : Arcan; 2007

23. Martin, R.M, Smith, G.D, Frankel, S., Gunnel, D. Association between breast feeding and growth: the Boyd-Orr cohort study. Arch Dis Child Fetal Neonatal Ed; 87 : F193-F201;2002

24. Gibney,J. Michael, Barney, M.Margarets, John, M.K. dan Lenore, A. Gizi Kesehtaan Masyarakat. Jakarta : EGC; 2009 
25. Purwanti H.Konsep penerapan ASI eksklusif. Jakarta EGC ,2004. 3;5;24-9.

26. DepKes RI. Petunjuk Pelaksanaan Peningkatan ASI eksklusif: Departemen Kesehatan Republik Indonesia Jakarta; 2005

27. WHO. Global Strategy for Infant and Young Child Feeding: The Optimal Duration of Exlusive Breastfeeding, $54^{\text {th }}$ WHA. 2005.

28. Perera, Fernando, Warnakulasuria, dan Ranathunga. Feeding practices among children attending child welfare clinics in Ragama $\mathrm{MOH}$ area: a descriptive crosssectional study. International Breastfeeding Journal. 2011.

29. Pudjiaji, S. Ilmu Gizi Klinis pada Anak edisi ke-2. Jakarta : Balai penerbit FKUI hal. 16, 21-30;2003
30. Brown, J. E. et.al. Nutrition Trought the Life Cycle. International Student Edition, 3rd, Thomson Wardsworth. 2002

31. Williams, L dan Wilkins. Modern Nutrition in Health and Diseases ( $10^{\text {th }}$ ed). United States of America: A Wolters Kluwer Company;2006

32. Wong, DL. Buku Ajar Keperawatan Pediatrik Wong. Jakarta : Balai penerbit FKUI hal. 1-6, 21-30;2003.

33. Nutrisiani, F. Hubungan Pemberian Makanan Pendamping ASI (MP ASI) pada anak usia 0-24 bulan dengan kejadian diare di Wilayah Kerja Puskesmas Purwodadi Kecamatan Purwodadi Kabupaten Grobogan. Universitas Muhammadiyah Surakarta.2010. Available from http://eprints.ums.ac.id/9270/2/J410050 001.pdf. Diakses pada 25 April 2017. 